\title{
Long-term effects of the abandonment of grazing on steppe-like grasslands
}

\author{
Enyedi, Z. Márton ${ }^{1,2}$; Ruprecht, Eszter ${ }^{1 *}$ \& Deák, Mónika ${ }^{3,4}$ \\ ${ }^{1}$ Department of Taxonomy and Ecology, Babeş-Bolyai University, Republicii street 42, R-400015 Cluj Napoca_Romania; \\ ${ }^{2}$ E-mail enyedimarton@freemail.hu; ${ }^{3}$ Revoluţiei street 35, R-310174 Arad, Romania; ${ }^{4}$ E-mail akinoma@freemail.hu;: \\ ${ }^{*}$ Corresponding author; Tel +40 264592152; Fax+40 264431858; E-mail ruprecht@grbot.ubbcluj.ro
}

\begin{abstract}
Question: What are the consequences of grazing abandonment on the Stipa lessingiana dominated steppe-like grasslands? What is the relative importance of management and environmental factors in causing variation in species composition and abundance in the continuously grazed and abandoned grassland stands?

Location: Transylvanian Lowland, Romania.

Methods: Repeated vegetation mapping of a grassland stand, where grazing was abandoned 35 years ago; re-sampling six grassland stands surveyed 29-57 years ago. For revealing long-term changes in species composition and rank abundance PCoA ordination was applied. The relative importance of management and environmental factors in structuring vegetation were explored by CCA ordination. Diversity, evenness and the relative number and abundance of red-listed species were compared between managed and abandoned stands.

Results: Our results pointed out that grasslands which were formerly grazed and dominated by S. lessingiana, in the longterm absence of grazing, have been transformed into a $S$. pulcherrima dominated type. Management, probably by creating bare surfaces and preventing litter accumulation, had the strongest effect on the species composition and abundance in the grasslands. Abandoned grassland stands had lower diversity and evenness compared to continuously grazed stands. While at the same time, the relative number of threatened, rare species did not differ between managed and abandoned sites.

Conclusion: Maintaining extensively grazed, as well as unmanaged, Stipa dominated grasslands would be important in order to create various habitat conditions for plant species, especially threatened and rare species, and promote diversity on the landscape scale.
\end{abstract}

Keywords: Diversity; Management; Re-sampling; Romania; Stipa lessingiana; Stipa pulcherrima, Transylvanian Lowland.

Nomenclature: Tutin et al. (1964-1980).

\section{Introduction}

Grazing by large herbivores affects grassland communities through changes in net primary production (Noy-Meir et al. 1989), spatial heterogeneity (Adler \& Lauenroth 2000; Peco et al. 2006), vegetation structure (Sala 1988), species composition (Kahmen et al. 2002; Moog et al. 2002) and species diversity (Virágh \& Bartha 1996; Pykälä et al. 2005). The mode and magnitude of the grazing action and of the community reaction are both functions of the evolutionary history of grazing and productivity of the community (Naveh \& Whittaker 1979; Milchunas et al. 1988). Changes induced by grazing may also depend on the type of vegetation affected, since different plant species react differently to such disturbances (Belsky 1992; Lavorel et al. 1998). Abandonment of a pasture evolutionary adapted to grazing can also have significant effects on the vegetation. In this case, abandonment can also be viewed as a form of disturbance (Sala et al. 1996).

Results about dynamic processes in grasslands under grazing or after abandonment were mostly accumulated from other parts of the world (e.g. McNaughton 1979; Milchunas et al. 1988; Noy-Meir et al. 1989; Seabloom \& Reichman 2001), while eastern Eurasian steppes have been poorly studied (e.g. Lavrenko \& Karamysheva 1993; Sarychev 2005).

Steppe-like grasslands of central-eastern Europe have similar characteristics to the zonal steppes of eastern Eurasia, but here they are mostly represented by smaller, extra-zonal stands. We have very little information about the effect of grazing and abandonment on these steppelike grasslands (Cremene et al. 2005), hence we do not have a proper management system for their conservation. Today, plant ecologists and conservationists face serious grassland management problems in many parts of the world, since large areas of natural and semi-natural grasslands were abandoned from livestock grazing (Poschlod \& WallisDeVries 2002). Remaining grasslands have become extremely fragmented and their area decreased (Butaye et al. 2005), which has resulted in a subsequent decrease in species richness (Bakker \& Berendse 1999). 
These consequences illustrate the importance of grazing as a management type in order to maintain grassland species diversity and, on a larger scale, landscape scale processes (Luoto et al. 2003).

In this study, we investigated long-term (29-57 years) vegetation changes produced by abandonment vs persistent cattle and sheep grazing in the Transylvanian Lowland, Romania. The primary questions addressed were: 1 . What are the consequences of grazing abandonment on the species composition, abundance, diversity and presence of endangered species of the feather-grass dominated grasslands? 2. What are the factors determining species composition and abundance in these grasslands? We used two different and complementary approaches for the study of long-term changes: (a) we re-mapped a previously mapped 4.8 ha area and (b) we re-sampled vegetation (through floristic surveys) at three locations which were abandoned from grazing and three locations which have continued with livestock grazing.

\section{Material and Methods}

\section{Study area}

The Transylvanian Lowland (Câmpia Transilvaniei) is situated in the northern-central part of Romania. The climate is temperate continental with maximum precipitation in summer (June-August) (Kun et al. 2004). The natural vegetation is forest-steppe/forest. The extensive deforestation of the Transylvanian Lowland occurred more than 1000 years ago. At present, small remnants of oak (Quercus robur-Quercus petraea) and oak-hornbeam (Q. petraea-Carpinus betulus) woods can be found on the tops of the hills or on northern facing slopes, the remaining area being occupied by large agricultural fields and grasslands.

Steppe-like grasslands in the Transylvanian Lowland occur on steep slopes $\left(30^{\circ}-50^{\circ}\right)$ with southwestern, southern and southeastern orientation, on eroded carbonated chernozemic soils on sandstone, clay or marly substrate, representing the most xeric grassland types of the region. Well-conserved steppe-like grasslands today are scarce, being considered as remnants of the extended Eurasian steppe zone from the Boreal (Soó 1949). The studied vegetation types are dominated by feather-grass species: Stipa lessingiana (Stipetum lessingianae) and Stipa pulcherrima (Stipetum pulcherrimae). Traditional management of the steppe-like grasslands was grazing by sheep or cattle from spring to autumn. In the last 15 years livestock have decreased in this region due to the low profitability and because these dry grasslands have the lowest yield $(600 \mathrm{~g}$ $\mathrm{m}^{-2} \mathrm{yr}^{-1}$ ) compared to other, more mesic, grassland types, they were the first to be abandoned.

\section{Vegetation mapping}

We used a 1968 vegetation map from a small nature reserve (4.8 ha) in the village Suatu $\left(46^{\circ} 46^{\prime} \mathrm{N}, 23^{\circ} 58^{\prime}\right.$ $\mathrm{E}, 440 \mathrm{~m}$ a.s.l.). Here the mean annual precipitation is $615 \mathrm{~mm}$ and the mean annual temperature is $8.5^{\circ} \mathrm{C}$. The grassland stand is situated on the S-SW slope $\left(35-40^{\circ}\right.$ slope) of Bánffy Hill. The map was drawn shortly after grazing was stopped. Vegetation types were defined based on the dominant or codominant species (if it was the case) and the map was drawn at a 1:100 resolution (Resmeriţă 1971). To detect the 35 year impact of the removal of grazing we made a second vegetation map in 2003 following the same methodology as in the case of the former mapping (1968) for defining vegetation types and drawing the map.

\section{Field sampling}

We chose six grassland stands for long-term comparison (Table 1). We gained old vegetation data (one to three phytosociological relevés of $5 \mathrm{~m} \times 5 \mathrm{~m}$ ) about these grasslands from the literature (Soó 1949; Csűrös et al. 1961; Şuteu 1979) and during 2004 we re-localized these grassland stands on the field by the locality, name and orientation of the hill mentioned in the old sources. We used only those grassland stands which could be unambiguously localized and when the vegetation was homogenous. After re-localization we established five $4 \mathrm{~m} \times 4 \mathrm{~m}$ plots in each of the grasslands by visually estimating the percent cover of vascular plant species. We also noted the amount of litter (\% abundance), bare ground (\% cover), exposure, slope degree and position on the slope (upper, middle, bottom). In two of the stands vegetation sampling was carried out in June-July 2004, and four stands were sampled in 2005 (Table 1). History of land use (management type) was determined by asking local people: from the six grasslands each grazed in the past three were abandoned (29-57 years ago) and three were continuously grazed (Table 1 ).

\section{Data analyses}

We geo-coded and digitalized the 1968 and 2003 vegetation maps. In order to compare the temporal changes in terms of replacement of different vegetation types between 1968 and 2003 the two maps were overlaid, and transition probabilities between each pair of vegetation types were calculated and arranged into a transition matrix.

In order to investigate long-term community development in the six grassland stands re-sampled 
Table 1. Site, sampling and vegetation characteristics in the six re-sampled grassland stands. Abbreviations: A.y.p. = average annual precipitation; $\mathrm{T}=$ mean annual temperature; Date 1 (old) = year of first sampling; Date 2 (new) = year of re-sampling; Manag. = management type as g. = grazed by, aban. = abandoned; Vegetation characteristics as average abundance $(\%)$ of the dominant species (S. 1. = Stipa lessingiana, S. p. = Stipa pulcherrima $)$.

\begin{tabular}{|c|c|c|c|c|c|c|c|c|c|c|c|c|c|}
\hline \multirow[b]{2}{*}{ Location } & \multicolumn{7}{|c|}{ Site characteristics } & \multicolumn{6}{|c|}{ Sampling and vegetation characteristics } \\
\hline & Coordinates & $\begin{array}{l}\text { Altitude } \\
\text { (m) }\end{array}$ & $\begin{array}{l}\text { A.y.p. } \\
(\mathrm{mm})\end{array}$ & $\begin{array}{l}\mathrm{T} . \\
\left({ }^{\circ} \mathrm{C}\right)\end{array}$ & $\begin{array}{c}\text { Slope } \\
\text { exposure }\end{array}$ & $\begin{array}{c}\text { Slope } \\
\text { degree }\left({ }^{\circ}\right)\end{array}$ & $\begin{array}{l}\text { Size } \\
\text { (ha) }\end{array}$ & $\begin{array}{l}\text { Date } 1 \\
\text { (old) }\end{array}$ & Manag. & $\begin{array}{l}\text { Vegetation } \\
\text { characteristics }\end{array}$ & $\begin{array}{c}\text { Date } 2 \\
\text { (new) }\end{array}$ & Manag. & $\begin{array}{l}\text { Vegetation } \\
\text { characteristics }\end{array}$ \\
\hline 1. Tirimia & $\begin{array}{l}46^{\circ} 27^{\prime} \mathrm{N} \\
24^{\circ} 30^{\prime} \mathrm{E}\end{array}$ & 425 & 600 & 8.7 & W-SW & $35-40$ & 2.2 & 1976 & g. sheep & $\begin{array}{l}\text { S. } 1 .=24.2 \\
\text { S. p. }=0\end{array}$ & 2005 & aban. & $\begin{array}{l}\text { S. } 1 .=0.4 \\
\text { S. p. }=45\end{array}$ \\
\hline 2. Puini & $\begin{array}{l}46^{\circ} 54^{\prime} \mathrm{N} \\
24^{\circ} 01^{\prime} \mathrm{E}\end{array}$ & 400 & 633 & 8.5 & SE-SW & $35-50$ & 1.4 & 1948 & g. sheep & $\begin{array}{l}\text { S. } 1 .=62.5 \\
\text { S. p. }=0\end{array}$ & 2005 & aban. & $\begin{array}{l}\text { S. } 1 .=0.1 \\
\text { S. p. }=46\end{array}$ \\
\hline 3. Sărmăşel & $\begin{array}{l}46^{\circ} 45^{\prime} \mathrm{N} \\
24^{\circ} 11^{\prime} \mathrm{E}\end{array}$ & 440 & 540 & 8.7 & W-S & $20-35$ & 3.5 & 1961 & g. sheep & $\begin{array}{l}\text { S. } 1 .=19 \\
\text { S. p. }=0.3\end{array}$ & 2004 & aban. & $\begin{array}{l}\text { S. } 1 .=3.1 \\
\text { S. p. }=18.2\end{array}$ \\
\hline 4. Cojocna & $\begin{array}{l}46^{\circ} 45^{\prime} \mathrm{N} \\
23^{\circ} 50^{\prime} \mathrm{E}\end{array}$ & 350 & 615 & 8.5 & SE-SW & $30-40$ & 2.4 & 1948 & g. cattle & $\begin{array}{l}\text { S. } 1 .=62.5 \\
\text { S. p. }=0\end{array}$ & 2005 & g. sheep & $\begin{array}{l}\text { S. } 1 .=22.4 \\
\text { S. p. }=0.3\end{array}$ \\
\hline 5. Sucutard & $\begin{array}{l}46^{\circ} 54^{\prime} \mathrm{N} \\
24^{\circ} 04^{\prime} \mathrm{E}\end{array}$ & 380 & 633 & 8.5 & S-SW & $30-40$ & 2.3 & 1948 & g. sheep & $\begin{array}{l}\text { S. } 1 .=62.5 \\
\text { S. p. }=0\end{array}$ & 2005 & g. sheep & $\begin{array}{l}\text { S. } 1 .=28 \\
\text { S. p. }=0\end{array}$ \\
\hline $\begin{array}{l}\text { 6. Valea } \\
\text { Florilor }\end{array}$ & $\begin{array}{l}46^{\circ} 40^{\prime} \mathrm{N} \\
23^{\circ} 52^{\prime} \mathrm{E}\end{array}$ & 464 & 550 & 8.6 & W-SW & $35-50$ & 3.2 & 1961 & g. cattle & $\begin{array}{l}\text { S. } 1 .=37.5 \\
\text { S. p. }=0.5\end{array}$ & 2004 & g. cattle & $\begin{array}{l}\text { S. } 1 .=11.2 \\
\text { S. p. }=0.6\end{array}$ \\
\hline
\end{tabular}

old and new relevés were subjected to Principal Co-ordinates Analysis (PCoA) with Euclidean distance as resemblance function using Syn-Tax 2000 (Podani 1997). In the case of old data sets cover-abundance of species in relevés was assessed according to Braun-Blanquet (1932), and in the case of new data we estimated the percent cover of plant species present in a plot. In order to make the old and new samples comparable, species abundances were considered as rank values:

$1=0-1 \% ; 2=1-5 \% ; 3=5-25 \% ; 4=25-50 \% ; 5=$ $50-75 \% ; 6=75-100 \%$. Probability ellipses (Podani 1997) were used to superimpose the classification on the ordination diagrams.

Because sampling methodology and scale differed slightly between old and new samples, and some environmental variables were missing in case of old samples, we only used the samples made by us (new) in the subsequent more detailed analysis. In case of new samples we used Canonical Correspondence Analysis (CCA) using CANOCO 4.5 (ter Braak \& Šmilauer 2002) to explore the relative importance of management and environmental factors (exposure, slope inclination, position on the slope) in accounting for variation in species composition and species abundance. Management was considered as a binary variable (grazed or abandoned); exposure as a continuous variable introduced in the analysis as degrees (from $\mathrm{SE}=135^{\circ}$ to $\mathrm{SW}=225^{\circ}$, the warmest exposure, values are increasing, then from SW $=225^{\circ}$ to $\mathrm{W}=180^{\circ}$ the values are decreasing as the micro-temperatures of the slopes are decreasing); position on the slope was coded by binary dummy variables; species data as percent cover.

When the effect of a variable was tested, other variables were used as covariates to partial out their effect. In the case of testing interactions, all variables and all other interactions were used as covariables. This procedure is analogous to the calculation of Type III sum of squares in general linear models (Grafen $\&$ Hails 2002). The probability of a Type I error was estimated by Monte Carlo permutation test using 9999 permutations.

In the case of species affected by any of the explanatory variables the following species traits were considered: life form, life span according to Sanda et al. (1983) and growth form according to the Biolflor database (Kühn et al. 2004; http://www.biolflor.de). In the case of species missing from the BiolFlor database we have taken into consideration the growth form of a similar species from the same genus.

We compared the amount of litter, cover of bare ground, Shannon-diversity, evenness, relative number and abundance of red-listed species (Boşcaiu et al. 1994; Dihoru \& Dihoru 1994; Oltean \& Negrean 1994) in newly sampled plots between grazed and abandoned groups with the Mann-Whitney $U$-test. 


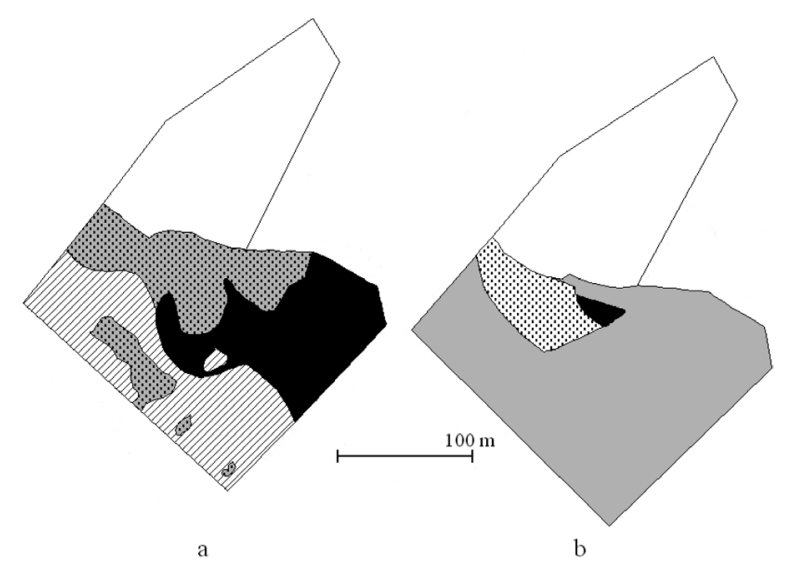

Fig. 1. Repeated mapping of the grassland from Suatu (Nature Reserve I.): vegetation map from (a) 1968 and (b) 2003. Striped = Dichanthium ischaemum and Carex humilis dominated type (A); Grey with dots = Stipa capillata dominated type (B); Grey = Stipa pulcherrima dominated type $(\mathrm{C})$; Black = Stipa lessingiana dominated type (D); White with dots = Stipa capillata, $S$. lessingiana and $S$. pulcherrima dominated vegetation type (E); White $=$ other, meso-xeric vegetation types. Capitals after each vegetation type are explanations for Table 2.

\section{Results}

Vegetation changes induced by the abandonment of grazing in the re-mapped Suatu grassland

We found great differences in the two vegetation maps, from 1968 (Fig. 1a) and 2003 (Fig. 1b), both in the type and relative cover of the vegetation types (Table 2 ). Vegetation types had been transformed during the 35 years in the absence of grazing. The most striking change was the transformation of several vegetation types into a Stipa pulcherrima dominated type, thus in 2003 this formerly absent vegetation type occupied the greatest part of the grassland (Fig. 1, Table 2). The Stipa lessingiana and the Dichanthium ischaemum - Carex humilis dominated types had transformed significantly $(98.5 \%$ and $94.5 \%$, respectively) into a $S$. pulcherrima dominated type, while only $59.2 \%$ of the S. capillata dominated type had also transformed into the $S$. pulcherrima type. Another remarkable, but less considerable change was the transformation of different vegetation types into a Stipa capillata - S. lessingiana - S. pulcherrima dominated type between 1968 and 2003 (Fig. 1, Table 2).

Long-term vegetation changes in the six re-sampled grassland stands

All six grasslands selected for re-sampling were grazed in the past and their dominant species was S. lessingiana. In three locations where grazing was continuous the
Table 2. Transition matrix of different xeric grassland types in the Suatu nature reserve between 1968 and 2003. Transition probabilities (\%) estimated by transition frequencies are shown. Grassland types are noted with capitals, for explanation see the legend of Fig. 1.

\begin{tabular}{|c|c|c|c|c|c|c|}
\hline & 2003 & A & B & C & D & E \\
\hline \multicolumn{7}{|c|}{1968} \\
\hline A & & 0 & 0 & 94.5 & 0 & 5.5 \\
\hline B & & 0 & 0 & 59.2 & 5.4 & 35.4 \\
\hline C & & 0 & 0 & 0 & 0 & 0 \\
\hline D & & 0 & 0 & 98.5 & 0 & 1.5 \\
\hline E & & 0 & 0 & 0 & 0 & 100 \\
\hline
\end{tabular}

grassland remained dominated by S. lessingiana, while in the other three locations where grazing had ceased 29-57 years ago, the grasslands became dominated by S. pulcherrima (Table 1).

PCoA ordination of the vegetation samples from these six locations revealed further differences between the grazed and abandoned grasslands, these two groups being separated along the first axis of the ordination diagram (Fig. 2), and the segregation was significant (Probability ellipses: $t=9.27, \mathrm{df}=35, p<0.0001$ ). In addition, old samples are separated from new samples along axis 2 .

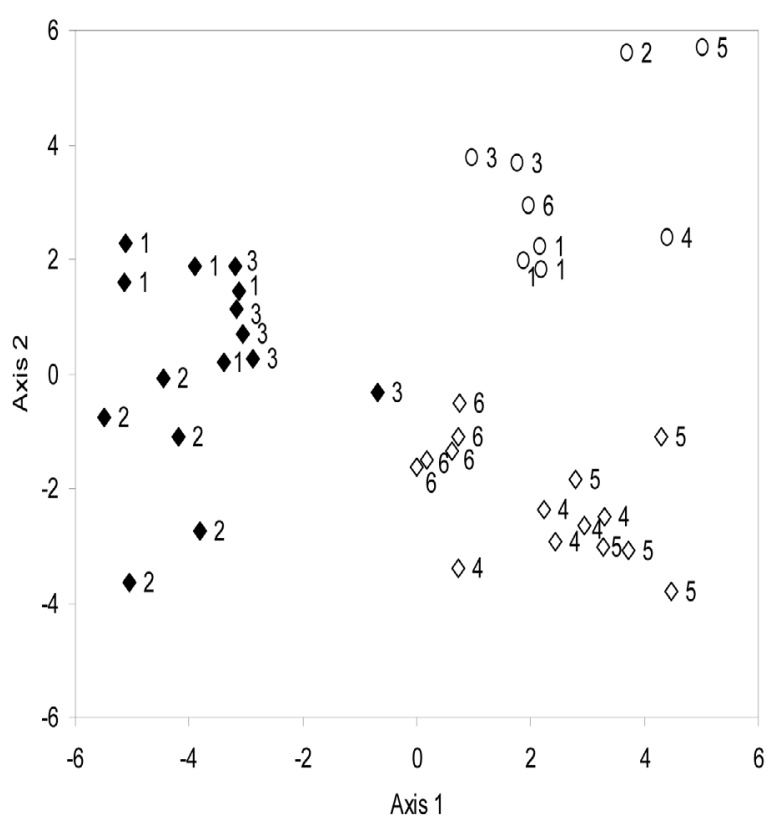

Fig. 2. PCoA ordination diagram of vegetation samples from grasslands in six locations (1-6, for explanation see Table 1) sampled by different people $29-57$ years ago $(\bigcirc)$ and resampled by us in 2004 or $2005(\diamond)$. Open symbols represent samples originating from managed grasslands and filled symbols samples originating from abandoned grasslands. Eigenvalues: axis $1=20.41 \%$, axis $2=11.95 \%$. 
Table 3. Results of the CCA analysis: the relative importance of management and environmental factors (exposure, slope inclination, position on the slope) accounting for variation in species composition and species abundance in the steppe-like grasslands.

\begin{tabular}{lccc}
\hline Effect & $p$-value & \multicolumn{2}{c}{$\begin{array}{c}\text { Explained variation } \\
\text { eigenvalue }\end{array}$} \\
& & & \\
& & & \\
Main effects & & & \\
Management & 0.0001 & 0.374 & 18.04 \\
Slope degree & 0.0178 & 0.096 & 4.63 \\
Exposure & 0.1339 & 0.075 & 3.62 \\
Position on the slope: top & 0.4286 & 0.056 & 2.70 \\
Position on the slope: bottom & 0.5075 & 0.053 & 2.56 \\
& & & \\
Two-way interactions & & & \\
Slope degree * management & 0.0005 & 0.153 & 7.38 \\
Exposure * management & 0.0027 & 0.108 & 5.21 \\
Slope degree * exposure & 0.0162 & 0.091 & 4.39 \\
Slope degree * position: bottom & 0.0262 & 0.085 & 4.10 \\
Management * position: bottom & 0.1961 & 0.058 & 2.80 \\
Exposure * position: bottom & 0.3464 & 0.05 & 2.41 \\
Exposure* position: top & 0.3279 & 0.05 & 2.41 \\
Management * position: top & 0.3811 & 0.047 & 2.27 \\
Slope degree * position: top & 0.5353 & 0.042 & 2.03 \\
& & & \\
\hline
\end{tabular}

Factors determining actual species composition and abundance in the steppe-like grasslands

As the results of the CCA analysis show, management played the most important role in determining the actual species composition and abundance of the grasslands studied (Table 3). Hieracium praealtum subsp. bauhinii, Sanguisorba minor, Leontodon crispus, Astragalus monspessulanus, Stipa lessingiana, Potentilla cinerea, Koeleria macrantha, Festuca rupicola, Dichanthium ischaemum, Thymus spp. and Asperula cynanchica were the species, all long-lived perennials of predominantly hemicryptophyte life form, favoured by management. Another group of species: Teucrium chamaedrys, Vinca herbacea, Filipendula vulgaris, Stipa pulcherrima, Galium verum and Coronilla varia, long-lived perennials, mostly hemicryptophytes, were characteristic of abandoned grassland stands. Between the species preferring the presence of grazing there were only two erosulate species, the rest of the species being rosette-forming or hemirosette plants, while species appearing predominantly in the lack of management were predominantly erosulate species and oply two were hemirosette plants http://www.biolflor.de. The dominant species were also among those preferring management (S. lessingiana), or avoiding managed sites (S. pulcherrima). Beside management, slope degree significantly explained species composition and rank abundance, and the interaction between slope degree and management also had a significant effect (Table 3). Several species were influenced more positively or less negatively by management in situations with high slope degree than in situations with low slope degree: i.e. Nepeta ucranica (red-listed species), Plantago argentea, Serratula radiata (red-listed species) and Carex humilis, while others were negatively or less positively influenced by management in situations with high or low slope degree: i.e. Dorycnium pentaphyllum ssp. herbaceum, Elymus hispidus and Acinos arvensis. The slope aspect had no significant effect on species data, but it modified the effect of slope degree and management (i.e. there were significant interactions). Position on the slope showed not to be important in explaining the species composition of the steppe-like grasslands (Table 3).

In grazed plots the cover of bare ground was significantly higher, while the abundance of litter was smaller than in plots from abandoned stands (Table 4). Species diversity and evenness in plots from grazed stands were higher than those in plots from unmanaged grasslands (Table 4). In the six studied steppe-like grasslands we found 17 red-listed species. There was no significant difference between the grazed and abandoned grasslands in the relative number of red-listed species; nevertheless the relative cover of these species was significantly higher in the case of the grazed grasslands (Table 4).

\section{Discussion}

Our results, obtained by different methods, pointed out the great impact of abandonment on the steppelike grasslands in the Transylvanian Lowland. Over a long term (30-60 years) formerly grazed grasslands, dominated by Stipa lessingiana, in the absence of graz-

Table 4. Vegetation characteristics in plots of grazed and abandoned grasslands (values are medians + lower quartiles). The two groups were compared with the Mann-Whitney $U$-test $\left(n_{1}=n_{2}=15\right)$.

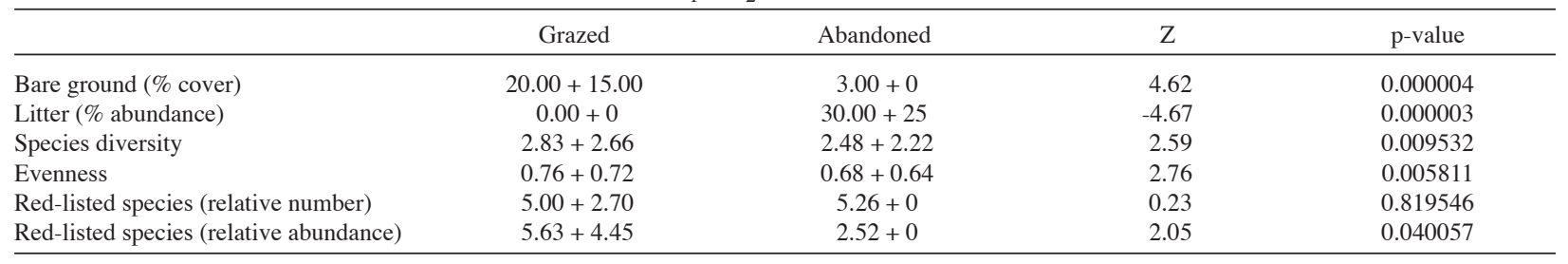


ing may transform into a $S$. pulcherrima dominated type. However, permanent grazing can maintain the former vegetation type.

By comparing the two vegetation maps, representing different stages of the same grassland stand, we can see a mosaic like transformation series rather than a complete transformation between two vegetation types. It seems that past grazing in the Suatu grassland brought about the appearance of several vegetation types. These vegetation types, in the 35 years of absence of grazing, had transformed gradually into other vegetation types. Understanding such a transformation series based on two discrete states of one grassland stand is uncertain and needs further investigation. On the other hand, a fundamental conclusion can be drawn that, in the long-term, following abandonment of grazing, the transformation of several xeric vegetation types into a Stipa pulcherrima dominated type, which represents the final stage of the transformation series, is very probable.

Based on the position of old (historical data) and new samples of the same grassland stand in the ordination space (Fig. 2) it is apparent that both the continuously grazed and abandoned grasslands have changed between the two sampling occasions, but in different directions: continuously grazed stands moved only along axis 2 , while abandoned stands moved along both ordination axes. Vegetation changes experienced in the case of the stands continuously grazed can be due either to the real changes in species composition and abundance because changes e.g. in grazing intensity, or to the different sampling approach and plot size applied during the two surveys, or most probably to the spatial heterogeneity of the vegetation, since the plots studied were not permanent plots. Changes in species composition and abundance was more intense in case of grassland stands which were formerly grazed and later abandoned than in the case of stands with continuous management.

The mechanisms by which the removal of grazing influences vegetation structure and composition are numerous (Virágh \& Bartha 1996; Olff \& Ritchie 1998), and are strongly connected with local environmental conditions (Skarpe 2000; Vesk et al. 2004). Our results show that geographical factors such as slope inclination and aspect can influence the effect of grazing on species composition and abundance (Table 3 ). On steep slopes, trampling and trampling induced soil erosion have proved to be beneficial, mostly for some rosetteforming and hemirosette-plants, which is in line with the findings of Noy-Meir et al. (1989) and Kahmen et al. (2002). Stipa lessingiana, the dominant species of grazed grasslands, was also favoured by management, while $S$. pulcherrima thrived by the lack of manage- ment. Being a semi-desert species, S. lessingiana is more adapted to arid environmental conditions than $S$. pulcherrima (Lavrenko \& Karamysheva 1993). Nevertheless, in dry areas the effect of drought provides a selection pressure that is complementary to that of grazing (Sala et al. 1996). Following abandonment, the trampling induced erosion is probably slowed down, which may play an important role in the mechanisms of replacement between the two dominant species as well as in the changes in species composition of the abandoned grasslands.

Litter accumulation, together with decreasing bare soil surfaces, are other consequences of the abandonment, as we found higher litter abundance and smaller amount of bare surfaces in abandoned sites, which may have serious effects on vegetation dynamic changes. Many studies demonstrated the control of litter over the structure and functioning of plant communities and ecosystems (reviewed by Facelli \& Pickett 1991; Xiong \& Nilsson 1999; Weltzin et al. 2005).

Contrary to the results of Cremene et al. (2005) who have studied different succession stages of abandoned steppe-like grasslands in the Transylvanian Lowland, we found that species diversity in abandoned grassland stands was lower than in continuously grazed stands, which was probably due to the strong dominance of some species, especially Stipa pulcherrima and Carex humilis, these species being in high abundance in abandoned stands. Their strong dominance could lead to changing abundance structure of the vegetation, as detected by the decreased levels of evenness. After our observations, in abandoned sites the major part of the accumulated litter is composed of the dead leaves of S. pulcherrima, thus litter accumulation can be a possible competitive mechanism by which $S$. pulcherrima can displace subordinate species leading to species loss and changing community composition and structure. Increased cover of the dominant species with abandonment is often reported in literature (e.g. Virágh \& Bartha 1996; Kahmen et al. 2002), and it leads to the competitive exclusion of subordinate species, as observed by Moog et al. (2002) in semi-natural grasslands. Without disturbance, which permanently creates bare surfaces and suppresses dominants from subsequent spread, the abundance and number of subordinate species declines in the longer-term, as we found significantly lower diversity in case of abandoned grassland stands. These findings are in line with the results of numerous other studies, which have also shown that plant species richness in grasslands declines after cessation of livestock grazing (e.g. Luoto et al. 2003; Mitchley \& Xofis 2005; Pykälä et al. 2005). 


\section{Assessment from a nature conservation point of view}

In the case of the re-mapped and re-sampled steppelike grasslands from the Transylvanian Lowland the presence of management predicted more diverse $S$. lessingiana dominated grasslands, while abandonment leads to a S. pulcherrima dominated grassland, highly affected by litter. On the other hand, endangered and rare species (red-listed species) were equally represented in grazed and abandoned grasslands, but their relative abundance was greater in managed stands. Following abandonment, the increased structural diversity of the habitat during succession favours the diversity of invertebrates, mostly that of the diurnal and nocturnal Lepidoptera, as found by Cremene et al. (2005) in the case of similar steppelike habitats in Transylvania.

With regard to the higher plant diversity of managed steppe-like grasslands, but the equal representation of rare and endangered plant species in the grazed and abandoned grassland stands, as well as the results of Cremene et al. (2005) referring to invertebrate communities, a mosaic of extensively grazed grasslands and different succession stages of unmanaged feather-grass dominated grasslands should be preserved in order to maintain a high diversity of habitats and thus high landscape-scale diversity.

Acknowledgements. We thank Zoltán Botta-Dukát for his help in data analysis and valuable comments and Anna Szabó for assistance during the field work. We are grateful to Tibor Vizauer for discussions about invertebrate communities, as well as to Mark Pillich-Wright and Gyöngyvér Pillich-Wright for improving the English.

\section{References}

Adler, P.B. \& Lauenroth, W.K. 2000. Livestock exclusion increases the spatial heterogeneity of vegetation in Colorado shortgrass steppe. Applied Vegetation Science 3: 213-222.

Bakker, J.P. \& Berendse, F. 1999. Constraints in the restoration of ecological diversity in grassland and heathland communities. Trends in Ecology and Evolution 14: 63-68.

Belsky, A.J. 1992. Effects of grazing, competition, disturbance and fire on species composition and diversity in grassland communities. Journal of Vegetation Science 3: 187-200.

Boşcaiu, N., Coldea, G. \& Horeanu, C. 1994. Red list of extinct, threatened, vulnerable and rare vascular plant species of Romania (Lista roşie a plantelor vasculare dispărute, periclitate, vulnerabile şi rare din flora României). Ocrotirea naturii şi a mediului înconjurător 38: 45-56. (in Romanian.)

Braun-Blanquet, J. 1932. Plant sociology: the study of plant communities. McGraw-Hill, New York, NY, US.
Butaye, J., Adriaens, D. \& Honnay, O. 2005. Conservation and restoration of calcareous grasslands: a concise review of the effects of fragmentation and management on plant species. Biotechnology, Agronomy, Society and Environment 9: 111-118.

Cremene, C., Groza, G., Rakosy, L., Schileyko, A.A., Baur, A., Erhardt, A. \& Baur, B. 2005. Alterations of steppe-like grasslands in Eastern Europe: a threat to regional biodiversity hotspots. Conservation Biology 19: 1606-1618.

Csûrös, I., Resmeriţă, I., Csûrös-Káptalan, M. \& Gergely, I. 1961. Grasslands from the Transylvanian Lowland and considerations about their management (Contibuţii la cunoaşterea pajiştilor din Câmpia Transilvaniei şi unele consideraţiuni cu privire la organizarea terenului). Studia Universitatis Babeș-Bolyai, Biologia 2: 15-61.

Dihoru, G. \& Dihoru, A. 1994. Rare, threatened and endemic plant species of Romania - the Red List (Plante rare, periclitate şi endemice în flora României - Lista Roşie). Acta Botanica Horti Bucurestiensis 173-199.

Facelli, J.M. \& Pickett, S.T.A. 1991. Plant litter: Its dynamics and effects on plant communitie structure. The Botanical Review 57: 1-32.

Grafen, A. \& Hails, R. 2002. Modern statistics for the life sciences. Oxford University Press, Oxford, UK.

Kahmen, S., Poschlod, P. \& Schreiber, K.F. 2002. Conservation management of calcareous grasslands. Changes in plant species composition and response of functional traits during 25 years. Biological Conservation 104: 319-328.

Kühn, I., Durka, W. \& Klotz, S. 2004. BiolFlor - a new planttrait database as a tool for plant invasion ecology Diversity and Distributions 10: 363-365. (http://www.biolflor.de)

Kun, A., Ruprecht, E. \& Szabó, A. 2004. The bioclimatological characteristics of the Transylvanian Basin (Romania) (Az Erdélyi-medence bioklimatológiai jellemzése). Múzeum Füzetek 13: 63-81. (in Hungarian with English summary.)

Lavorel, S., Touzard, B., Leberton, J.D. \& Clément, B. 1998. Identifying functional groups for response to disturbance in an abandoned pasture. Acta Oecologia 19: 227-240.

Lavrenko, E.M. \& Karamysheva, Z.V. 1993. Steppes of the former Soviet Union and Mongolia. In: Coupland, R.T. (ed.) Ecosystems of the World, 8B. Natural Grasslands. Eastern Hemisphere and Resumé, pp. 3-59. Elsevier, Amsterdam, NL.

Luoto, M., Pykälä, J. \& Kuussaari, M. 2003. Decline of landscape-scale habitat and species diversity after the end of cattle grazing. Journal of Natural Conservation 11: 171-178.

McNaughton, S.J. 1979. Grazing as an optimization process: grass-ungulate relationship in the Serengetti. The American Naturalist 113: 691-703.

Milchunas, D.G., Sala, O.E. \& Laurenroth, W.K. 1988. A generalized model of grazing by large herbivores on grassland community structure. The American Naturalist 132: 87-106.

Mitchley, J. \& Xofis, P. 2005. Landscape structure and management regime as indicators of calcareous grassland habitat condition and species diversity. Journal of Natural Conservation 13: 171-183. 
Moog, D., Poschlod, P., Kahmen, S. \& Schreiber, K.F. 2002. Comparison of species composition between different grassland management treatments after 25 years. Applied Vegetation Science 5: 99-106.

Naveh, Z. \& Whittaker, R.H. 1979. Structural and floristic diversity of shrublands and woodlands in Northern Israel and other mediterranean areas. Vegetatio 41: 171-190.

Noy-Meir, I., Gutman, M. \& Kaplan, Y. 1989. Responses of mediterranean grassland plants to grazing and protection. Journal of Ecology 77: 290-310.

Olff, H. \& Ritchie, M.E. 1998. Effects of herbivores on grassland plant diversity. Trends in Ecology and Evolution 13: 261-265.

Oltean, M. \& Negrean, G. 1994. Red list of vascular plants from Romania (Lista roşie a plantelor superioare din România). Studii, sinteze, documentaţii de Ecologie 1: 1-52.

Peco, B., Sánchez, A.M. \& Azcárate, F.M. 2006. Abandonment in grazing systems: Consequences for vegetation and soil. Agriculture, Ecosystems and Environment 113: 284-294.

Podani, J. 1997. Introduction into the multivariate data analysis in biology (Bevezetés a többváltozós biológiai adatfeltárás rejtelmeibe). Scientia Kiadó, Budapest, HU. (in Hungarian.)

Poschlod, P. \& WallisDeVries, M.F. 2002. The historical and socioeconomic prospective of calcareous grasslands-lessons from the distance and recent past. Biological Conservation 104: 361-376.

Pykälä, J., Luoto, M., Heikkinen, R.K. \& Kontula, T. 2005. Plant species richness and persistence of rare plants in abandoned semi-natural grasslands in northern Europe. Basic and Applied Ecology 6: 25-33.

Resmeriţă, I. 1971. The nature reserve from Suatu (Rezervaţia Botanică de la Suatu). Ocrotirea Naturii 15: 129-138.

Sala, O.E. 1988. The effect of herbivory on vegetation structure. In: Werger, M.J.A., van der Aart, P.J.M., During, H.J. \& Verhoeven, J.T.A. (eds.) Plant form and vegetation structure, pp. 317-330. SPB, The Hague, NL.

Sala, O.E., Lauenroth, W.K., McNaughton, S.J., Rusch, G. \& Xinshi Zhang, A. 1996. Biodiversity and ecosystem functioning in grasslands. In: Mooney, H.A., Cushman, J.H., Medina, E., Sala, O.E. \& Schulze, E.D. (eds.) Functional roles of biodiversity: A global perspective, pp. 129-149. Wiley, Chichester, UK.

Sanda, V, Popescu, A., Doltu, M.I. \& Doniţă, N. 1983. Caracterizarea ecologică şi fitocenologică a speciilor spontane din flora României (Ecological and fitosociological characteristics of the native flora of Romania). Studii şi Comunicări 25: 5-126, supplement.

Sarychev, V. 2005. Steppe communities in Central Russia (Lipetsk Province): On the verge of destruction or a new life? In: Struchkov, A. \& Kuleshova, J. (eds.) Facets of grassland restoration. Selected papers from the International Field Seminar held at Galichya Gora Nature Reserve (Russia), 16-22 June 2003, pp. 1-18. The Open Country Series, Moscow, RU.

Seabloom, E.W. \& Reichman, O.J. 2001. Simulation models of the interactions between herbivore foraging strategies, social behavior, and plant community dynamics. The American Naturalist 157: 76-95.
Skarpe, C. 2000. Desertification, no-change or alternative states: Can we trust simple models on livestock impact in dry rangelands? Applied Vegetation Science 3: 261-268.

Soó, R. 1942. Die Endemismen und Reliktarten des Siebenbürgischen Beckens (Az Erdélyi Medence endemikus és reliktum növényfajai). Acta Geobotanica Hungarica 5: 141-183. (in Hungarian with German summary.)

Soó, R. 1949. Les associations végétales de la MoyenneTransylvanie II. Les associations des marais, des prairies et des steppes. Acta Geobotanica Hungarica 6: 3-107.

Şuteu, Ş. 1979. Vegetation investigations on the Alunaş Slope (Tirimia, District of Mureş) (Cercetări de vegetaţie pe Coasta Alunaşului (Tirimia - Jud. Mureş)). Contribuţii Botanice 143-154.

ter Braak, C.J.F. \& Šmilauer, P. 2002. CANOCO reference manual and CanoDraw for Windows. User's guide: software for canonical community ordination (version 4.5). Microcomputer Power, Ithaca, NY, US.

Tutin, T.G., Heywood, V.H., Burges, N.A., Moore, D.M., Valentine, D.H., Walters, S.M. \& Webb, D.A. 1964-1980. Flora Europaea. Vols. 1-5. Cambridge University Press, Cambridge,UK_(Florg Europaea (URL: http://rbg-web2. rbge.org.uk/FE/fe.htm]; last accessed: 20.02.2007)

Vesk, P.A., Leishman, M.R. \& Westoby, M. 2004. Simple traits do not predict grazing response in Australian dry shrublands and woodlands. Journal of Applied Ecology 41: 22-31.

Virágh, K. \& Bartha, S. 1996. The effect of current dynamical state of a loess steppe community on its responses to disturbances. Tiscia 30: 3-13.

Weltzin, J.F., Keller, J.K., Bridgham, S.D., Pastor, J., Allen, P.B. \& Chen, J. 2005. Litter controls plant community composition in a northern fen. Oikos 110: 537-546.

Xiong, S. \& Nilsson, C. 1999. The effects of plant litter on vegetation: a meta analysis. Journal of Ecology 87: 984994.
Received 1 August 2006; Accepted 13 April 2007; Co-ordinating Editor: B. Peco. 